\title{
ANALISIS GREEN INOVATION DAMPAKNYA TERHADAP KEUNGGULAN BERSAING PRODUK DAN KINERJA PEMASARAN (STUDI EMPIRIK PADA UKM BATIK CIWARINGIN KABUPATEN CIREBON)
}

\author{
Lili Karmela Fitriani \\ Fakultas Ekonomi \\ Universitas Kuningan
}

\begin{abstract}
This paper examines the relationship between green product innovation, green process innovation, competitive advantage of product and market performance in the SMEs Ciwaringin batik Cirebon West Java. A survey of 93 SMEs batik provides the basis for the empirical investigation. The relationships between the green innovation product, competitive advantage of product and market performance are examined using stepwise regression. The findings show that green product innovation not contributes positively to competitive advantage of product and market performance. Another findings of this study is that the impact of green process innovation contributes positively to competitive advantage of product but not to market performance in the SMEs Ciwaringin batik. Competitive advantage of product has impact to market performance. This paper also discusses the recomendations of the results.
\end{abstract}

Keywords:

Innovation, Green product innovation, Green ProcessIinnovation, Product Market Performance, Competitive advantage. 


\section{PENDAHULUAN}

Menghadapi tantangan-tantangan dalam menghadapi persaingan bisnis saat ini sebuah perusahaan harus dapat bertahan dan maju dengan melakukan inovasi. Inovasi hanya dapat terjadi dalam suatu sistem yang terkait dengan komitmen dari para manajer, struktur organisasi yang kondusif, kemampuan pengidentifikasian dan pemanfaatan sumber-sumber inovasi, sumber daya manusia yang kreatif, dan lain-lain. Inovasi dapat menghasilkan berbagai produk yang dapat memenuhi permintaan pasar dengan varian yang beraneka ragam. Inovasi merupakan dasar untuk mencapai keunggulan bersaing, Inovasi adalah proses yang mengubah bentuk gagasan/ide baru ke dalam nilai baru. Inovasi tidak dapat dilakukan tanpa ada kreatifitas. Inovasi merupakan faktor yang penting bagi organisasi-organisasi untuk bersaing di pasar secara efektif (Hitt dan Irreland, 2001). Organisasi-organisasi harus fokus pada inovasi secara intensif untuk membedakan dirinya dari para pesaing. Untuk hidup dan tumbuh secara kontinyu, sebuah organisasi harus berinovasi dalam rangka membentuk ulang keunggulan bersaing mereka. Produk yang unik akan membuat konsumen bisa melihat keunggulan yang signifikan terhadap masing-masing produk. Keunggulan bersaing merupakan implikasi penciptaan nilai yang unik dan unggul dibandingkan pesaing.

Konsep green economic saat ini sudah mulai banyak digunakan dalam berbagai kegiatan perekonomian. Demikian halnya dengan perusahaan-perusahaan yang berusaha menciptakan produk yang ramah lingkungan. Dampak lingkungan merupakan konsekuensi dari terus meningkat kegiatan industri . Kebijakan perbaikan dalam beberapa dekade terakhir telah diimplementasikan untuk memperbaiki lingkungan seperti kerusakan. Dalam rangka untuk melindungi kehidupan dunia kita, diperlukan untuk mengadopsi pendekatan preventif terhadap pencemaran lingkungan . Dalam rangka menghilangkan masalah pencemaran lingkungan , konsep pengelolaan lingkungan, seperti green management, green marketing, green product dan green innovation, dll sekarang sedang digalakkan. Munculnya peraturan lingkungan internasional, seperti Montreal Convention , Kyoto Protocol , Restriction Pemanfaatan Bahan Berbahaya Tertentu di EEE (RoHS), dan Limbah Elektronik dan Listrik Equipment ( WEEE ), dan kesadaran konsumen mengenai lingkungan akan membawa dampak signifikan terhadap bisnis di dunia ( Chen et al.,2006) . Oleh karena itu, pengelolaan lingkungan merupakan hal penting dalam organisasi dan semakin menjadi bagian penting dari agenda manajemen.

Green product innovation telah menjadi salah satu kunci bagi perusahaan untuk terus berkembang dan menghasilkan kualitas produk yang lebih baik. Pemahaman green innovation merupakan hasil dari interaksi antara inovasi dengan teori sustainability. (Rosa Maria, et al., 2010).

Terdapat beberapa perbedaan hasil penelitian mengenai pengaruh Green Inovation terhadap keunggulan bersaing, seperti dapat dilihat pada Tabel 1 . 
Tabel 1.

Penelitian Terdahulu

\begin{tabular}{|c|c|}
\hline Nama, Tahun, Judul & Temuan \\
\hline $\begin{array}{l}\text { Shan Chen, Yu, et al (2006), The Influence of } \\
\text { Green Innovation Performance on Corporate } \\
\text { Advantage in Taiwan }\end{array}$ & $\begin{array}{l}\text { Kinerja inovasi (Kinerja green product innovation dan } \\
\text { green process innovation). Memiliki hubungan positif } \\
\text { dengan keunggulan bersaing perusahaan. Kinerja green } \\
\text { product innovation lebih baik dibanding kinerja green } \\
\text { process innovation. }\end{array}$ \\
\hline $\begin{array}{l}\text { Hsun Chang, Ching (2011), The Influence of } \\
\text { Corporate Environmental ethics on } \\
\text { Competitive Advantage: The Mediation Role } \\
\text { of Green Innovation }\end{array}$ & $\begin{array}{l}\text { Kinerja inovasi (green product innovation dan green } \\
\text { process innovation) Green product innovation dapat } \\
\text { memediasi hubungan positif etika lingkungan dengan } \\
\text { keunggulan bersaing, green product innovation dapat } \\
\text { menangkap peluang memimpin pasar. Green process } \\
\text { innovation tidak bisa memediasi hubungan etika lingkungan } \\
\text { dengan keunggulan bersaing }\end{array}$ \\
\hline $\begin{array}{l}\text { Wahid, et al (2011), Product, process and } \\
\text { combined green innovations on firm's } \\
\text { competitive advantages }\end{array}$ & $\begin{array}{l}\begin{array}{l}\text { Green product innovation dan green process innovation } \\
\text { berpengaruh terhadap kinerja keunggulan } \\
\text { berusahaan. }\end{array} \\
\end{array}$ \\
\hline $\begin{array}{l}\text { Lin, Ru-Jen, et al., (2013) Market demand, } \\
\text { green product innovation, and firm } \\
\text { performance: evidence from Vietnam } \\
\text { motorcycle industry }\end{array}$ & $\begin{array}{l}\text { Green Product Innovation berpengaruh positif terhadap } \\
\text { kinerja pemasaran }\end{array}$ \\
\hline
\end{tabular}

Sektor UKM sering digambarkan sebagai sektor yang mempunyai peran penting dalam pembangunan di Indonesia, karena sebagian besar kegiatan ekonomi bergerak di bidang usaha kecil dan menengah. UKM memberikan kontribusi yang signifikan pada pembangunan ekonomi antara lain berperan dalam penyerapan tenaga kerja, peningkatan ekonomi lokal dan peningkatan nilai ekspor (Murtadlo, 2013).

Menghadapi pasar global yang penuh persaingan membuat UKM harus mampu meningkatkan kualitasnya, sehingga produknya memiliki keunggulan untuk bersaing. Bagi UKM, produk berkualitas yang dihasilkan merupakan hal yang utama, karena konsumen dapat membandingkan produk yang mereka peroleh dengan produk lainnya. Adanya keluhan dari konsumen mengenai kualitas produk seharusnya dapat menjadi informasi dan masukan bagi pihak UKM untuk dapat melakukan tindakan perbaikan dan meningkatkan kualitas produk yang diberikan sehingga memiliki keunggulan untuk bersaing.

Batik merupakan warisan budaya dunia yang berasal dari Indonesia. Menjadikan batik sebagai ikon Indonesia mensyaratkan adanya penguatan batik sebagai warisan budaya sekaligus penggalian potensi ekonominya sebagai industri (Wahyono, 2011). Batik dinilai sebagai ikon budaya yang memiliki keunikan dan filosofi mendalam, serta mencakup siklus kehidupan manusia, sehingga ditetapkan sebagai warisan budaya tak benda dari kemanusiaan (Murtadlo, 2013).

Kabupaten Cirebon memiliki usaha kreatif dan inovatif yang perlu terus dikembangkan agar memiliki daya saing terhadap daerah lain yaitu batik yang merupakan warisan budaya yang memiliki filosofi terhadap makna kehidupan. Persaingan yang semakin ketat, karena semakin terbukanya pasar di dalam negeri merupakan ancaman bagi UKM. Fenomena 
saat ini dengan diberlakukannya pasar bebas antara China dengan negara-negara Asean membuat begitu mudahnya produk China masuk ke dalam negeri, demikian halnya dengan produk batik. Serbuan batik Cina ini sudah terjadi sejak empat tahun silam yang membuat resah sejumlah pengrajin. Berbekal harga murah dan motif yang menarik, batik Cina diperkirakan dapat menguasai pangsa pasar yang dapat mengancam keberadaan batik tanah air.

Untuk meningkatkan kualitas dan mampu bersaing di pasar, pengrajin batik tulis Cirebon harus mampu meningkatkan kreatifitas tinggi dan mempertahankan motif tradisional serta mampu memenuhi keinginan pasar. Hal ini merupakan tantangan untuk terus meningkatkan inovasi dalam rangka meningkatkan keunggulan bersaing terutama terhadap batik-batik impor dengan harga yang lebih terjangkau. Kreatifitas dalam membuat corak dan tepat membidik segmen pasar dapat menjadi kunci utama dalam menangkal serbuan batik pesaing. Inovasi sangat dibutuhkan untuk mempertahankan keunggulan batik lokal dari batik-batik impor. Kreatifitas dalam merancang motif batik dengan penggunaan bahan-bahan yang berasal dari alam diharapkan menjadikan produk batik lebih menarik dan unggul. Menciptakan produk batik yang lebih kompetitif sesuai dengan permintaan pasar. Kemampuan pemilik UKM dalam menciptakan produk yang lebih baik dan menarik diharapkan akan meningkatkan keunggulan bersaing dan berdampak pada kinerja pemasaran.

Berdasarkan research gap dan fenomena bisnis batik dalam menghadapi persaingan maka dilakukan penelitian tentang pengaruh Green innovation terhadap keunggulan bersaing produk dan kinerja pemasaran. Hal ini dilakukan karena batik Ciwaringin dalam prosesnya menggunakan bahan pewarna alami yang cenderung memiliki sedikit dampak terhadap lingkungan sehingga memiliki keunggulan.

\section{LANDASAN TEORI}

Grant (1991) mengemukakan pentingnya sumber daya dan kapabilitas perusahaan. Model ini memfokuskan pada pembentukan produk yang berkualitas dan unggul, sulit ditiru oleh pesaing. Objek penelitian ini adalah UKM batik Ciwaringin di Kabupaten Cirebon.

\subsection{Green Inovation}

Inovasi dalam sebuah perusahaan merupakan kebutuhan mendasar yang pada gilirannya mampu menciptakan keunggulan bersaing. Inovasi merupakan sebuah fungsi penting dari manajemen karena inovasi akan menentukan suatu kinerja bisnis yang superior. Inovasi menjadi semakin bertambah penting sebagai suatu alat untuk kelangsungan hidup, bukan hanya pertumbuhan tetapi juga dalam persaingan yang semakin ketat dan ketidakpastian lingkungan (Han, et. al 1998).

Menurut Han et.al (1998) munculnya inovasi produk pada dasarnya adalah untuk memenuhi permintaan pasar, sehingga inovasi produk merupakan salah satu yang dapat digunakan sebagai keunggulan kompetitif bagi perusahaan.Tekanan persaingan yang semakin kuat dari hari ke hari dan perubahan kebutuhan yang sangat cepat mengharuskan perusahaan menemukan sesuatu yang baru baik berupa metode, produk, maupun pasar guna meraih keunggulan bersaing perusahaan. Perusahaan dituntut untuk mengembangkan produk atau jasa secara terus menerus supaya perusahaan dapat mempertahankan kelangsungan hidupnya (Robbins, 1994). Oleh karena itu kegiatan inovasi harus dirancang dan dikembangkan karena inovasi merupakan 
sumberdaya dan kompetensi yang tidak dapat dilakukan dengan tergesa-gesa.

Amstrong et.al (2008) membedakan inovasi menjadi dua bagian yaitu (1) inovasi proses, melibatkan pengembangan manajemen dan praktek baru organisasi, (2) inovasi produk, melibatkan aplikasi pengetahuan dan pengembangan produk baru yang berwujud dan pelayanan baru. Sedangkan Neely et.al (2005) membedakan inovasi dalam perusahaan terdiri atas: (1) inovasi produksi, seperti perubahan desain, komponen dan arsitektur produk, (2) inovasi jasa, seperti perubahan cara melayani konsumen dan pelayanan baru, (3) inovasi proses, seperti adaptasi lini produk baru yang sudah ada dan implementasi teknologi atau proses baru, (4) inovasi pasar, seperti eksploitasi teritori pasar yang baru, penetrasi segmen pasar baru, (5) inovasi logistic, seperti model logistic yang baru untuk mencapai bahan baku outbound logistic yang baru (terhadap konsumen), (6) inovasi organisasi, seperti system manajerial yang baru dan adaptasi organisasi.

Inovasi produk, didefinisikan sebagai sebuah inovasi produk radikal dan inovasi produk tambahan. Inovasi produk radikal mengacu pada produk yang berbeda fitur dan atribut kinerja yang menciptakan satu set manfaat yang tersedia dari produk yang ada dalam perspektif pelanggan. Di sisi lain, tambahan inovasi produk mengacu pada produk yang memiliki perubahan kecil dalam atributnya, yang bermanfaat dalam perspektif pelanggan. (Fred Langerak, Erik Jan Hultink et al. 2004) menunjukkan inovasi produk sebagai sejauh mana produk-produk baru yang diperkenalkan kepada target market dan menciptakan seperangkat manfaat tersedia untuk para pelanggan (Ziamou dan Ratneshwar, 2003), meskipun bentuk fisik dari produk yang ditawarkan tidak baru ke pasar.
Eco - inovasi, menurut Oltra dan Saint Jean ( 2009) didefinisikan sebagai inovasi lingkungan yang terdiri dari proses baru atau perubahan proses, praktek, sistem dan produk yang bermanfaat bagi lingkungan dan sebagainya yang berkontribusi terhadap kelestarian lingkungan. (Chen, Lai et al. 2006), mendefinisikan green inovation sebagai perangkat keras atau perangkat lunak inovasi yang berhubungan dengan green product atau proses, termasuk inovasi dalam teknologi yang terlibat hemat energi, pencegahan polusi, daur ulang limbah, desain green product, atau pengelolaan lingkungan perusahaan.

Green innovation berpengaruh secara signifikan meningkatkan kinerja lingkungan pengembangan dan pengelolaan perusahaan, yang sebagian dilakukan untuk memenuhi persyaratan peraturan lingkungan (Chen, Lai et al. 2006). Green Innovation dikenal sebagai inovasi yang berkelanjutan yaitu sebuah proses dimana pertimbangan keberlanjutan seperti lingkungan, keuangan sosial diintegrasikan ke dalam sistem perusahaan dari tahap ide melalui penelitian dan pengembangan $(\mathrm{R} \& \mathrm{D})$ dan komersialisme. Proses keberlanjutan dampak terhadap produk, layanan, teknologi, dan bisnis dan organisasi model baru (Charter \& Clark, 2007). Klemmer (1999) mendefinisikan green innovation sebagai techno-ekonomi, organisasi, sosial dan perubahan kelembagaan yang menghasilkan perbaikan kualitas lingkungan. Melalui seluruh siklus hidup green innovation, perbaikan lingkungan harus dapat menghasilkan pengurangan risiko lingkungan, polusi dan dampak negatif lainnya dari sumber daya yang digunakan dibandingkan alternatif yang relevan (Kemp, 2006). Ide green innovation pada proses dan produk tidak hanya mencakup pada pemecahan tuntutan lingkungan, kekurangan sumber daya, undang-undang 
lingkungan baru, tekanan publik, namun juga kebutuhan pelanggan, dan tindakan pesaing (Nunes \& Bennet, 2010).

\subsubsection{Green Product Innovation}

Green Product Innovation adalah proses multi-fase dimana tiga fokus utama lingkungan yaitu, material, energi, dan polusi disorot berdasarkan dampak yang besar pada lingkungan pada tahap yang berbeda dari siklus hidup produk meskipun tidak semua produk memiliki dampak lingkungan yang signifikan pada setiap tahap siklus hidup produk fisik dari semua aspek (bahan, energi, dan polusi) tapi hampir semua produk memiliki dampak lingkungan yang signifikan dalam setidaknya satu dari tahap siklus hidup (Dangelico, et al., 2010).

Inovasi produk konvensional tidak benar-benar fokus pada perbaikan lingkungan , sementara green inovasi produk tujuannya adalah untuk mengurangi dan menghindari beban lingkungan. Green product innovation dapat menggabungkan target bisnis dengan tidak hanya mengurangi upaya pemotongan biaya tapi menghasilkan manfaat bagi lingkungan juga ( Triebswetter \& Wackerbauer, 2007)

Menurut Kammerer (2009), green product innovation bermanfaat bagi pelanggan karena selain memiliki manfaat ramah lingkungan, green prodct juga akan menghasilkan manfaat lingkungan pribadi bagi pelanggan, seperti penghematan energi, maka secara tidak langsung hal ini akan menciptakan lebih banyak permintaan dan perusahaan akan termotivasi untuk melaksanakan inovasi yang lebih baik. Selain itu, Dangelico dan Pujari (2010) menyarankan bahwa, total siklus hidup dampak produk pada lingkungan dapat dikurangi dari inovasi produk yang lebih ramah lingkungan. Upaya yang dilakukan antara lain, pengurangan berbahaya dan kelebihan bahan produk, peningkatan efisiensi energi dan output polusi, serta penggunaan diperpanjang atau daur ulang skema untuk produk usang.

Green Product Innovation membantu perusahaan untuk mendapatkan keunggulan kompetitif dengan membedakan produk mereka dari pesaing yang tidak melakukan green product innovation (Reinhardt , 1998) . Beberapa peneliti menyarankan bahwa green innovation pada produk perusahaan memberikan manfaat individu untuk konsumen (Ottman , 1998; Reinhardt, 1998; Belz \& Bilharz , 2005). Beberapa manfaat termasuk penghematan biaya dan energi karena peralatan lebih efisien, peningkatan kualitas dan daya tahan, medan elektromagnetik dan produk kurang beracun untuk mengurangi bahaya kesehatan. Green product innovation berpengaruh positif terhadap keunggulan bersaing ( Wong, 2012). Manfaat ini tidak hanya akan menciptakan nilai yang lebih baik bagi konsumen, tetapi juga mengangkat citra perusahaan dalam mempromosikan pertumbuhan berkelanjutan. Green Product Innovation berpengaruh positif terhadap kinerja pemasaran (Lin, Ru-Jen, et al., 2013). H1 : Green product innovation berpengaruh terhadap keunggulan bersaing produk

H3 : Green product innovation berpengaruh terhadap kinerja pemasaran

\subsubsection{Green Process Inovation}

Green Process Innovation tidak hanya mencakup proses rekayasa isu-isu seperti desain proses terkait tetapi juga aspek ekologi dan sosial yang terkait proses (Diwekar \& Shastri, 2010). Karakteristik kunci untuk green process adalah bahwa produk akhir yang diproduksi tidak mengandung bahan berbahaya dan diproses tanpa bahan kimia berbahaya. Selain itu , green process juga menggunakan energi dan sumber daya selama berproduksi secara efisien dan bijaksana . Hal ini akan 
mengurangi kemungkinan insiden lingkungan dan mengakibatkan peningkatan kualitas dan bisnis yang lebih menguntungkan ( Kuo, 2007). Green process innovation juga dikenal sebagai proses inovasi yang merupakan komposisi ramah lingkungan dari satu atau lebih proses inovasi (misalnya, daur ulang air atau bahan bakar gas desulfurisasi ), terlepas dari realisasi inovasi produk lingkungan (Zieglera \& Nogaredac , 2009).

Penelitian yang dilakukan Chen et al ( 2006) menemukan bahwa green process innovation memiliki dampak positif pada keunggulan kompetitif perusahaan. Alasan utama untuk ini adalah bahwa dengan green proses, limbah dapat dikurangi dan didaur ulang serta energi digunakan dalam cara yang lebih efisien . Kuo ( 2007 ) menyatakan bahwa dengan menerapkan green manufacture bisnis akan mencapai daya saing yang lebih baik dari peningkatan kualitas dan efisien penggunaan energi dan sumber daya selama produksi. Perusahaan juga dapat mencapai keuntungan yang lebih tinggi dengan angka yang lebih rendah dari dampak lingkungan karena produk jadi mengandung lebih banyak bahan-bahan alami dan diproses tanpa bahan beracun . Green process innovation berpengaruh positif terhadap keunggulan bersaing (Wong, 2012).

H2 : Green process innovation berpengaruh terhadap keunggulan bersaing produk

H4 : Green process innovation berpengaruh terhadap keunggulan bersaing produk

\subsection{Keunggulan Bersaing Produk}

Inovasi produk dapat membantu perusahaan tidak hanya membedakan diri dari pesaing tapi memberikan manfaat yang unik dan unggul untuk pelanggan mereka (Hunt dan Morgan, (1995); Zhou, Yim, dan David (2005)), juga untuk meningkatkan keunggulan biaya atas produk pesaing dengan memperkenalkan produk serupa dengan harga lebih rendah. Manfaat yang unik dan unggul harus memenuhi kebutuhan pelanggan (Day dan Nedungadi, 1994; Danupol, 2009). Sumber keunggulan kompetitif adalah teknologi dan inovasi. Keunggulan kompetitif tidak bisa bekerja tanpa koordinasi untuk menghasilkan inovasi.

Song dan Montoya-Weiss (2001) mendefinisikan keunggulan produk dalam hal persaingan sebagai "produk yang dirasakan relatif superioritas terhadap produk kompetitif", sedangkan Calantone dan Di Benedetto (1988) menyatakan keunggulan produk untuk kebutuhan pelanggan mengacu pada manfaat yang dirasakan pelanggan berasal dari produk-produk baru. Slater dan Narver (2000) menyatakan bahwa keunggulan produk mengarah ke penciptaan nilai superior bagi pelanggan relatif dibanding apa yang ditawarkan oleh pesaing.

Keunggulan produk adalah penentu penting keberhasilan produk dan layanan baru (Hultink dan Hurt, 1998; Cooper, 2000; Montoya-Weiss dan Calantone, 1994), dan menurut Langerak et al., (2004) untuk menghasilkan kinerja produk baru yang unggul dan kinerja organisasi. Hua dan Wemmerlo (2006) menyatakan bahwa keunggulan produk adalah tingkat persepsi desain produk, atribut, dan kualitas relatif terhadap persaingan. Menurut Cooper (2000) pentingnya produk baru yang sukses menjadi kualitas yang lebih tinggi daripada produk yang bersaing.

Menurut Porter (1990) keunggulan bersaing adalah jantung kinerja pemasaran untuk menghadapi persaingan. Hasil penelitian Li ( 2000) berhasil menemukan adanya pengaruh positif antara keunggulan bersaing dengan kinerja yang diukur melalui volume penjualan, tingkat keuntungan, pangsa pasar, dan return on investment. Keunggulan bersaing dapat diperoleh dari 
kemampuan perusahaan untuk mengelola dan memanfaatkan sumber daya dan modal yang dimilikinya. Perusahaan yang mampu menciptakan keunggulan bersaing akan memiliki kekuatan untuk bersaing dengan perusahaan lainnya karena produknya akan tetap karena produknya akan tetap diminati pelanggan. Keunggulan bersaing memilki pengaruh positif terhadap peningkatan kinerja pemasaran perusahaan.

Keterkaitan antara keunggulan yang unik dengan kinerja penjualan diukur dari pertumbuhan penjualan oleh tingkat pendapatan penjualan, profitabilitas, return on investment, hasil, nilai tambah produk dan pangsa pasar (Wang, 2008). Keunggulan bersaing berpengaruh terhadap kinerja perusahaan yang terdiri atas kinerja pemasaran dan kinerja keuangan (Suhong Li, et al., 2006).

H5: $\begin{gathered}\text { Keunggulan } \\ \text { berpengaruh } \\ \text { pemasaran }\end{gathered}$
terhadap

\subsection{Kinerja Pemasaran}

Pengukuran kinerja pada perusahaan kecil dan menengah dianjurkan untuk menggunakan pendekatan pertumbuhan karena perusahaan kecil pada umumnya memiliki laporan keuangan yang tidak transparan dan sulit diinterpretasikan (Miles, et al, 1998). Pengukuran yang tepat terhadap kinerja UKM belum ada kesepakatan umum. Untuk mengantisipasi tidak adanya ketersediaan data kinerja bisnis secra objektif dalam penelitian dimungkinkan untuk menggunakan ukuran kinerja secara subjektif yang didasarkan pada persepsi manajer atau pemilik (Covin dan Slevin, 1989; Covin \& Covin, 1990). Penelitian yang berkaitan dengan kewirausahaan mengukur kinerja perusahaan dengan menggunakan ukuran atau indikator yang berbeda-beda. Menurut Wiklund (1999), pertumbuhan penjualan merupakan indikator kinerja yang lazim dan telah menjadi konsensus sebagai ukuran kinerja yang baik.

Beberapa peneliti menjelaskan indikator tentang kinerja bisnis UKM seperti Miles et. al (1998) menggunakan pendekatan pertumbuhan karena perusahaan kecil pada umunya memiliki laporan keuangan yang tidak transparan dan sulit diinterpretasikan. Krauss (2006) menyatakan ukuran kinerja dilihat dari pertumbuhan tenaga kerja, pertumbuhan penjualan, dan evaluasi kesuksesan eksternal. Selanjutnya Lee dan Badri (2007) mengelompokkan kinerja bisnis dengan financial effectiveness dan non financial effectiveness. Menurut hasil penelitian Stamp et. al (2008) mengukur kinerja usaha dengan dimensi pertumbuhan penjualan, pertumbuhan tenaga kerja, market share, gross profit, net profit margin, inovasi dan pelayanan, biaya pengawasan dan kepuasan konsumen.

Kinerja pemasaran merupakan bagian dari kinerja organisasi. Menurut Voss dan Voss (2000) kinerja pasar didefinisikan sebagai usaha pengukuran tingkat kinerja yang meliputi omzet penjualan, jumlah pembeli, keuntungan dan pertumbuhan penjualan. Kinerja pemasaran merupakan ukuran prestasi yang diperoleh dari aktifitas proses pemasaran secara menyeluruh dari sebuah perusahaan atau organisasi. Kinerja perusahan dilihat dari market atractiveness dapat diukur dengan ukuran pasar, pertumbuhan pasar, posisi pasar perusahaan, volume penjualan potensial, segmen pelanggan laten, dan jumlah pesaing saat ini (Jiménez-Zarco, Martínez-Ruiz et al. 2006). Kinerja pemasaran dapat diukur dengan pertumbuhan penjualan, pertumbuhan tenaga kerja dan market share. Kinerja pemasaran biasanya didasarkan pada pangsa pasar, laba, nilai pasar, pertumbuhan penjualan, jumlah karyawan, dan pertumbuhan produktivitas. (Corsino 2008). 


\section{METODE PENELITIAN}

\subsection{Model Penelitian}

Berdasarkan uraian yang telah dipaparkan pada landasan teori maka dapat dibuat model penelitian empiris (Gambar 1.) hasil pengembangan dari model penelitian Wahid et al., (2011) yang menghasilkan bahwa green product innovation dan green process innovation berpengaruh terhadap keunggulan bersaing. Model penelitian ini penulis menambah variabel kinerja pemasaran. Hal ini dilakukan karena menurut beberapa hasil penelitian bahwa inovasi dapat berpengaruh terhadap kinerja pemasaran (Ali Ekber Akgun, 2012; Bodlaj,2010) sebagai berikut :

H3

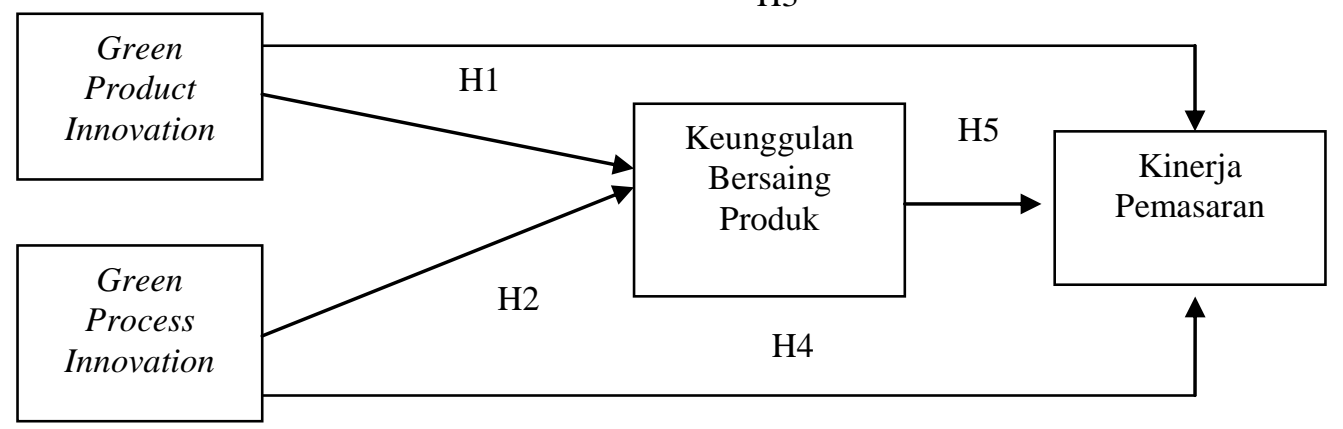

Gambar 1.

Model Penelitian Empiris

\subsection{Variabel Penelitian}

Variabel penelitian yang digunakan dalam penelitian ini adalah sebagai berikut:

a. Green product innovation: (1) Perusahaan memilih bahan produk yang menghasilkan paling sedikit polusi untuk melakukan pengembangan produk atau desain; (2) perusahaan memilih bahan dari produk yang mengkonsumsi paling sedikit energi dan sumber daya untuk melakukan pengembangan produk atau desain, (3) perusahaan menggunakan paling sedikit jumlah bahan untuk produk terdiri dari untuk melakukan pengembangan produk atau desain, (4) perusahaan mudah untuk mendaur ulang, dapat digunakan kembali, dan membusuk untuk melakukan pengembangan produk atau desain (Chen, 2006).

b.Green process innovation : (1) proses pembuatan produk secara efektif mengurangi emisi zat berbahaya atau limbah; (2) Proses perusahaan mendaur ulang limbah dan emisi yang memungkinkan mereka untuk dipelihara dan digunakan kembali, (3) proses perusahaan mengurangi konsumsi air, listrik, batubara, atau minyak; (4) perusahaan manufaktur mengurangi penggunaan bahan baku (Chen, 2006).

c. Keunggulan Bersaing Produk : (1) produk memiliki nilai lebih, (2) produk tidak mudah ditiru, (3) produk tidak mudah diganti oleh produk pesaing (Barney, 1991).

d.Kinerja Pemasaran : (1) tingkat pertumbuhan, (2) tingkat penjualan, (3) pertumbuhan pasar (Ferdinand, 2003).

\subsection{Populasi dan sampel}

Populasi dalam penelitian ini adalah pengrajin dan pengusaha Batik Ciwaringin 
Kabupaten Cirebon Jawa Barat. Berdasarkan data dari Disperindag tahun 2013 jumlah pengrajin batik di Kecamatan Ciwaringin sebanyak 117 pengrajin (Disperindag, 2013). Penentuan jumlah sampel yang digunakan adalah dengan metode sensus. Setelah kuesioner diedarkan ternyata hanya diperoleh 93 kuesioner karena pemiliknya sudah meninggal dan usahanya tidak memiliki penerus, ada pula yang usahanya sudah tidak ada, atau alamat tidak ditemukan. Analisis menggunakan regresi linier.

\section{HASIL PENELITIAN}

\subsection{Karakteristik Responden}

Karakteristik responden dari 93 orang pemilik atau pengelola UKM dapat dilihat dalam Tabel 2. sebagai berikut :

Tabel 2.

Karakteristik Responden

\begin{tabular}{|c|c|c|}
\hline Karakteristik Responden & Frekuensi & Prosentase \\
\hline \multicolumn{3}{|l|}{ Jenis Kelamin } \\
\hline a. Perempuan & 90 & $96,8 \%$ \\
\hline b. Laki-laki & 3 & $3,2 \%$ \\
\hline \multicolumn{3}{|l|}{ Usia } \\
\hline a. $<29$ tahun & 14 & $15,05 \%$ \\
\hline b. 30-39 tahun & 36 & $38,71 \%$ \\
\hline c. 40-50 tahun & 27 & $29,03 \%$ \\
\hline d. $>50$ tahun & 16 & $17,20 \%$ \\
\hline \multicolumn{3}{|l|}{ Pendidikan } \\
\hline a. SD & 45 & $48,39 \%$ \\
\hline b. SMP & 34 & $36,56 \%$ \\
\hline c. S1 & 2 & $2,15 \%$ \\
\hline d. lainnya & 12 & $12,90 \%$ \\
\hline \multicolumn{3}{|l|}{ Pengalaman Berusaha } \\
\hline a. $\leq 5$ tahun & 21 & $22,58 \%$ \\
\hline b. $6-10$ & 26 & $27,96 \%$ \\
\hline c. $>10$ tahun & 46 & $49,46 \%$ \\
\hline
\end{tabular}

Sumber : Hasil olah data, 2014

Berdasarkan Tabel 2. dapat diketahui responden sebagian besar adalah perempuan yaitu sebanyak 90 orang atau $96,8 \%$, dan laki-laki sebanyak 3 orang atau 3,2\%. Hal ini menggambarkan bahwa ukm batik identik dengan perempuan.

Responden dengan usia $<29$ tahun sebanyak 14 responden atau $15,05 \%$, usia antara 30-39 tahun sebanyak 36 responden atau $38,71 \%$, usia antara 40-50 tahun sebanyak 27 responden atau $29,03 \%$, usia > 50 tahun sebanyak 16 responden atau
17,20\%. Responden paling banyak berusia antara 30-39 tahun. Hal ini menggambarkan para pengusaha batik Ciwaringin di Kabupaten Cirebon tergolong masih cukup muda sehingga masih memiliki peluang untuk bisa lebih mengembangkan usaha mereka.

Responden berdasarkan tingkat pendidikan responden paling banyak adalah lulusan Sekolah Dasar (SD) sebanyak $48,39 \%$. Hal itu menggambarkan bahwa menurut responden dengan tingkat 
pendidikan SD sudah cukup mampu mengelola usaha.

Reponden berdasarkan pengalaman berusaha paling banyak berpengalaman di atas 10 tahun sebanyak $49,46 \%$. Hal itu menggambarkan bahwa sebaian besar pengusaha telah dan memiliki pengalaman berusaha yang cukup lama.

\subsection{Analisis Stepwise Regression}

Berdasarkan hasil analisis Coefficients dapat diketahui bahwa model regresi dapat dianalisis karena tidak memiliki multikolinearitas. Hal tersebut dapat diketahui dari hasil analisis pada masingmasing variabel memiliki nilai VIF untuk GIPd 1,018, Variabel GIPs 1,108 dan keunggulan bersaing sebesar 1,000.

\subsubsection{Hipotesis 1 dan 2}

Hasil uji untuk hipotesis 1 dan 2 dapat dilihat pada Tabel 3., Tabel 4., Tabel 5., Tabel 6., Tabel 7. Dan Tabel 8. berikut.

Tabel 3.

Correlation

\begin{tabular}{|c|c|c|c|}
\hline & בGIPd & GIPs & KBP \\
\hline $\begin{array}{c}\text { GIPd Pearson Correlation } \\
\text { Sig (2-tailed) } \\
\mathrm{N}\end{array}$ & $\begin{array}{r}1 \\
93\end{array}$ & $\begin{array}{r}0,134 \\
0,199 \\
93\end{array}$ & $\begin{array}{r}0,164 \\
0,116 \\
93\end{array}$ \\
\hline $\begin{array}{l}\text { GIPd Pearson Correlation } \\
\text { Sig (2-tailed) } \\
\mathrm{N}\end{array}$ & $\begin{array}{r}0,134 \\
0,199 \\
93\end{array}$ & $\begin{array}{r}1 \\
93\end{array}$ & $\begin{array}{r}0,381 * * \\
0,000 \\
93\end{array}$ \\
\hline $\begin{array}{ll}\text { KBP } & \text { Pearson Correlation } \\
\text { Sig (2-tailed) } \\
\text { N }\end{array}$ & $\begin{array}{r}0,164 \\
0,116 \\
93\end{array}$ & $\begin{array}{r}0,381 * * \\
0,000 \\
93\end{array}$ & $\begin{array}{r}1 \\
93\end{array}$ \\
\hline
\end{tabular}

Tabel 4.

ANOVA

\begin{tabular}{||cl||r|r||r||r||c||}
\hline \hline Model & Sum of Squares & \multicolumn{1}{|c||}{ Df } & Mean Square & F & Sig \\
\hline \hline 1 & Regression & 49,598 & 1 & 49,598 & 15,493 & 0,000 \\
& Residual & 291,327 & 91 & 3,201 & & \\
& Total & 340,925 & 92 & & & \\
\hline
\end{tabular}

a. Predictors : (Constant), GIPs

b. Green process innovation Dependent Variable : KBP

Tabel 5.

Coefficients

\begin{tabular}{|c|c|c|c|c|c|c|}
\hline & \multirow{2}{*}{ Model } & \multicolumn{2}{|c|}{ Unstandardized Cofficients } & \multirow{2}{*}{$\begin{array}{c}\begin{array}{c}\text { Standardized } \\
\text { Coefficients }\end{array} \\
\text { Beta }\end{array}$} & \multirow[b]{2}{*}{ t } & \multirow[b]{2}{*}{ Sig } \\
\hline & & $\overline{\mathbf{B}}$ & Std Error & & & \\
\hline 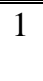 & $\begin{array}{l}\text { (Constant) } \\
\text { GIPs }\end{array}$ & $\begin{array}{r}23,290 \\
0,311 \\
\end{array}$ & $\begin{array}{l}1,940 \\
0,079\end{array}$ & 0,381 & $\begin{array}{r}12,002 \\
3,936 \\
\end{array}$ & $\begin{array}{l}0,000 \\
\mathbf{0 , 0 0 0}\end{array}$ \\
\hline
\end{tabular}

Dependent Variable : KBP

Pada Tabel 5. dapat dilihat bahwa berpengaruh terhadap keunggulan bersaing produk pada $\mathrm{t}=3,936$ dan sig 0,000, sehingga mendukung hipotesis 2 . 
Tabel 6.

Correlations

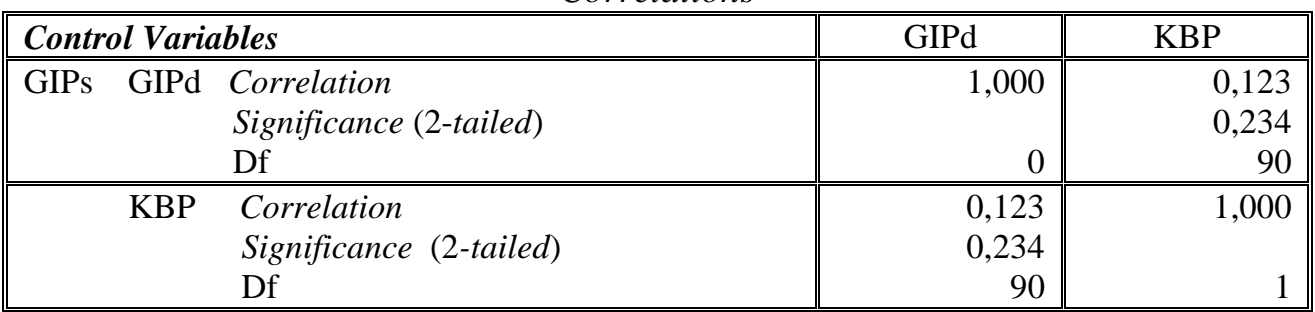

Tabel 7.

ANOVA

\begin{tabular}{|c|c|c|c|c|c|c|}
\hline & Model & Sum of Squares & Df & Mean Square & $\mathbf{F}$ & Sig \\
\hline 1 & $\begin{array}{l}\text { Regression } \\
\text { Residual } \\
\text { Total }\end{array}$ & $\begin{array}{r}54,002 \\
286,922 \\
340,925\end{array}$ & $\begin{array}{r}2 \\
90 \\
92\end{array}$ & $\begin{array}{r}27,001 \\
3,188\end{array}$ & 8,470 & 0,000 \\
\hline
\end{tabular}

a. Predictors : (Constant), GIPd, GIPs

b. Dependent Variable : KBP

Tabel 8.

Coefficients

\begin{tabular}{|c|c|c|c|c|c|c|}
\hline & \multirow{2}{*}{ Model } & \multicolumn{2}{|c|}{ Unstandardized Cofficients } & \multirow{2}{*}{$\begin{array}{c}\begin{array}{c}\text { Standardized } \\
\text { Coefficients }\end{array} \\
\text { Beta }\end{array}$} & \multirow[b]{2}{*}{$\mathrm{t}$} & \multirow[b]{2}{*}{ Sig } \\
\hline & & $\mathbf{B}$ & Std Error & & & \\
\hline \multirow[t]{3}{*}{1} & (Constant) & 21,633 & 2,395 & & 9,033 & 0,000 \\
\hline & GIPs & 0,298 & 0,080 & 0,366 & 3,750 & 0,000 \\
\hline & GIPd & 0,061 & 0,052 & 0,115 & 1,175 & 0,243 \\
\hline
\end{tabular}

Pada Tabel 8. dapat dilihat bahwa GIPd tidak berpengaruh pada keunggulan bersaing produk karena sig sebesar 0,243 > 0,05 , sehingga tidak mendukung hipotesis 1 .

Persamaan Regresi terbaik berdasarkan hasil analisis stepwise regression yang diperoleh adalah (Tabel 5 . coefficient pada $\mathrm{t}=3,936$ dan sig 0,000 ) yaitu :

$$
\begin{aligned}
& \mathbf{Y}=\mathbf{2 3}, \mathbf{2 9 0}+\mathbf{0 , 3 1 1 G I P s}+\mathbf{e} \\
& \text { Interpretasi } \quad \text { Model Linear: }
\end{aligned}
$$
Interpretasi dari hasil estimasi parameter dari persamaan regresi yang telah diperoleh, dapat dibuat suatu interpretasi terhadap suatu model atau hipotesis yang telah diambil pada metode penelitian ini, yaitu:

a. Konstanta bernilai 23,290 artinya jika tidak ada variabel bebas Green Process Innovation (GIPs) maka Keunggulan Bersaing Produk sebesar 23,290.

b.Variabel Green Process Innovation bertanda positif terhadap Keunggulan Bersaing Produk pada UKM batik Ciwaringin di Kabupaten Cirebon dengan koefisien regresi sebesar 0.311 artinya apabila terjadi peningkatan Green Process Innovation setiap satu satuan maka keunggulan bersaing akan meningkat sebesar 0.311 . 
Berdasarkan hasil analisis stepwise regression diperoleh hasil bahwa yang mempengaruhi keunggulan bersaing produk pada UKM batik Ciwaringin hanya green process innovation, sedangkan green process innovation tidak berpengaruh terhadap keunggulan bersaing produk. Hasil Penelitian ini juga membuktikan bahwa green process innovation mempengaruhi keunggulan bersaing produk. Hipotesis pertama terbukti, tetapi hipotesis kedua tidak terbukti.

\subsubsection{Hipotesis 3, 4 dan 5}

Hasil uji untuk hipotesis 3,4 dan 5 dapat dilihat pada Tabel 9., Tabel 10., Tabel 11., Tabel 12., Tabel 13., Tabel 14., Tabel 15., Tabel 16. Dan Tabel 17. berikut.

Tabel 9.

Correlation

\begin{tabular}{|c|c|c|c|c|c|}
\hline & & GIPd & GIPs & KBP & KP \\
\hline GIPd & $\begin{array}{l}\text { Pearson Correlation } \\
\text { Sig (2-tailed) } \\
\mathrm{N}\end{array}$ & 93 & $\begin{array}{r}0,134 \\
0,199 \\
93\end{array}$ & $\begin{array}{r}0,164 \\
0,116 \\
93\end{array}$ & $\begin{array}{r}-0,080 \\
0,444 \\
93\end{array}$ \\
\hline GIPs & $\begin{array}{l}\text { Pearson Correlation } \\
\text { Sig (2-tailed) } \\
\mathrm{N}\end{array}$ & $\begin{array}{r}0,134 \\
0,199 \\
93\end{array}$ & 93 & $\begin{array}{r}0,381 * * \\
0,000 \\
93\end{array}$ & $\begin{array}{r}0,228^{*} \\
0,028 \\
93\end{array}$ \\
\hline KBP & $\begin{array}{l}\text { Pearson Correlation } \\
\text { Sig (2-tailed) } \\
\mathrm{N}\end{array}$ & $\begin{array}{r}0,164 \\
0,116 \\
93\end{array}$ & $\begin{array}{r}0,381 * * \\
0,000 \\
93\end{array}$ & 93 & $\begin{array}{r}0,298 * * \\
0,004 \\
93\end{array}$ \\
\hline$\overline{\mathrm{KP}}$ & $\begin{array}{l}\text { Pearson Correlation } \\
\text { Sig (2-tailed) } \\
\mathrm{N}\end{array}$ & $\begin{array}{r}-0,080 \\
0,444 \\
93\end{array}$ & $\begin{array}{r}0,228^{*} \\
0,028 \\
93\end{array}$ & $\begin{array}{r}0,298 * * \\
0,004 \\
93\end{array}$ & $\begin{array}{r}1 \\
93\end{array}$ \\
\hline
\end{tabular}

**. Correlation is significant at the 0.01 level (2-tailed).

*. Correlation is significant at the 0.05 level (2-tailed).

Tabel 10.

ANOVA



a. Predictors : (Constant), KBP

b. Dependent Variable : KP

Tabel 11.

Coefficients

\begin{tabular}{|c|c|c|c|c|c|c|}
\hline & \multirow{2}{*}{ Model } & \multicolumn{2}{|c|}{ Unstandardized Cofficients } & \multirow{2}{*}{$\begin{array}{c}\begin{array}{c}\text { Standardized } \\
\text { Coefficients }\end{array} \\
\text { Beta } \\
\end{array}$} & \multirow[b]{2}{*}{$\mathbf{t}$} & \multirow[b]{2}{*}{ Sig } \\
\hline & & $\mathbf{B}$ & Std Error & & & \\
\hline & $\begin{array}{l}\text { (Constant) } \\
\text { KBP }\end{array}$ & $\begin{array}{l}\mathbf{9 , 8 8 7} \\
\mathbf{0 , 5 9 0} \\
\end{array}$ & $\begin{array}{l}6,134 \\
0,198 \\
\end{array}$ & 0,298 & $\begin{array}{l}1,612 \\
2,976 \\
\end{array}$ & $\begin{array}{l}0,110 \\
\mathbf{0 , 0 0 4}\end{array}$ \\
\hline
\end{tabular}

Dependent Variable : KP 
Pada Tabel 11. dapat dilihat bahwa keunggulan bersaing produk berpengaruh terhadap kinerja pemasaran pada $\mathrm{t}=2,976$ dengan sig 0,004 , sehingga mendukung hipotesis 5 .

Tabel 12.

Correlation

\begin{tabular}{|c|c|c|c|c|c|}
\hline \multicolumn{3}{|c|}{ Control Variables } & GIPd & GIPs & KP \\
\hline \multirow[t]{3}{*}{ "KBP } & GIPd & $\begin{array}{l}\text { Correlation } \\
\text { Significance (2-tailed) } \\
\text { Df }\end{array}$ & 1,000 & $\begin{array}{r}0,079 \\
0,455 \\
90\end{array}$ & $\begin{array}{r}-0,137 \\
0,192 \\
90\end{array}$ \\
\hline & GIPs & $\begin{array}{l}\text { Correlation } \\
\text { Significance (2-tailed) } \\
\text { Df }\end{array}$ & $\begin{array}{r}0,079 \\
0,455 \\
90\end{array}$ & $\bar{~} 1,000$ & $\begin{array}{r}0,129 \\
0,220 \\
90\end{array}$ \\
\hline & & Correlation & $\begin{array}{r}-0,137 \\
0,192 \\
90\end{array}$ & $\begin{array}{r}0,129 \\
0,220 \\
90\end{array}$ & $\bar{~} 1,000$ \\
\hline
\end{tabular}

Tabel 13.

ANOVA

\begin{tabular}{|ll||r||r||r||c||c|}
\hline \multicolumn{1}{|c|}{ Model } & Sum of Squares & \multicolumn{1}{|c|}{ Df } & Mean Square & F & Sig \\
\hline \hline 1 & Regression & 141,531 & 2 & 70,765 & 5,328 & 0,007 \\
& Residual & 1195,394 & 90 & 13,282 & & \\
& Total & 1336,925 & 92 & & & \\
\hline
\end{tabular}

a. Predictors : (Constant), GIPd, KBP

b. Dependent Variable : KP

Tabel 14.

Coefficients

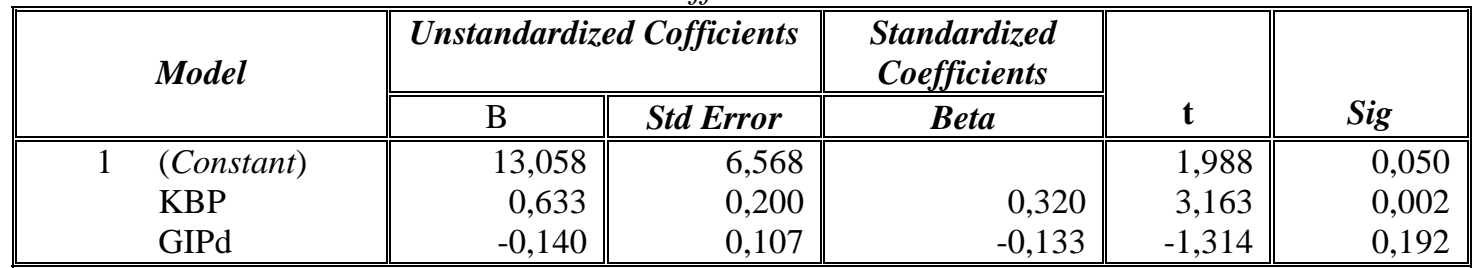

Dependent Variable : KP

Pada Tabel 14. dapat dilihat hasil untuk GIPd tingkat sig 0,192>0,05 sehingga tidak mendukung hipotesis 4 bahwa green product innovation tidak berpengaruh terhadap kinerja pemasaran. 
Tabel 15 .

Correlations

\begin{tabular}{|c|c|c|c|}
\hline \multicolumn{2}{|r|}{ Control Variables } & GIPs & KP \\
\hline KBP \& GIPc & $\begin{array}{ll}\text { GIPs } & \text { Correlation } \\
& \text { Significance (2-tailed) } \\
& \text { Df }\end{array}$ & 1,000 & $\begin{array}{r}0,142 \\
0,180 \\
89 \\
\end{array}$ \\
\hline & $\begin{array}{ll}\text { KP } & \text { Correlation } \\
& \text { Significance (2-tailed) } \\
& \text { Df }\end{array}$ & $\begin{array}{r}0,142 \\
0,180 \\
90 \\
\end{array}$ & 1,000 \\
\hline
\end{tabular}

Tabel 16.

ANOVA

\begin{tabular}{|c|c|c|c|c|c|}
\hline Model & Sum of Squares & Df & Mean Square & $\mathbf{F}$ & $\overline{\text { Sig }}$ \\
\hline $\begin{array}{ll}1 & \text { Regression } \\
& \text { Residual } \\
& \text { Total }\end{array}$ & $\begin{array}{r}165,557 \\
1171,368 \\
1336,925\end{array}$ & $\begin{array}{r}3 \\
89 \\
92 \\
\end{array}$ & $\begin{array}{l}55,186 \\
13,161\end{array}$ & 4,193 & 0,008 \\
\hline
\end{tabular}

a. Predictors : (Constant), GIPs, GIPd, KBP

b. Dependent Variable : KP

Tabel 17.

Coefficients

\begin{tabular}{|c|c|c|c|c|c|c|}
\hline & \multirow{2}{*}{ Model } & \multicolumn{2}{|c|}{ Unstandardized Cofficients } & \multirow{2}{*}{$\begin{array}{c}\begin{array}{c}\text { Standardized } \\
\text { Coefficients }\end{array} \\
\text { Beta }\end{array}$} & \multirow[b]{2}{*}{ t } & \multirow[b]{2}{*}{ Sig } \\
\hline & & $\mathbf{B}$ & Std Error & & & \\
\hline \multirow[t]{4}{*}{1} & (Constant) & 10,967 & 6,719 & & 1,632 & 0,106 \\
\hline & KBP & 0,527 & 0,214 & 0,266 & 2,458 & 0,016 \\
\hline & GIPd & $-0,152$ & 0,107 & $-0,144$ & $-1,423$ & 0,158 \\
\hline & GIPs & 0,235 & 0,174 & 0,145 & $-1,351$ & 0.180 \\
\hline
\end{tabular}

Dependent Variable : KP

Pada Ttabel 17. dapat dilihat tingkat sig untuk GIPd sebesar 0,158 dan sig GIPs sebesar 0,180 sehingga tidak mendukung hipotesis 3 dan 4 bahwa green product innovation dan green process innovation tidak berpengaruh terhadap kinerja pemasaran. Hasil analisis stepwise regression diperoleh persamaan regresi terbaik adalah pada Tabel 11. dengan $\mathrm{t}=$ 2,976 dan sig 0,004 yaitu :

\section{$\mathrm{Y}=\mathbf{9 , 8 8 7}+\mathbf{0 , 5 9 0 K B P}+\mathrm{e}$}

Interpretasi Model Linear:

Interpretasi dari hasil estimasi parameter dari persamaan regresi yang telah diperoleh, dapat dibuat suatu interpretasi terhadap suatu model atau hipotesis yang telah diambil pada metode penelitian ini, yaitu:

a. Konstanta bernilai 9,887 artinya jika tidak ada variabel bebas Keunggulan Bersaing Produk maka Kinerja Pemasaran sebesar 9,887 .

b. Variabel Keunggulan Bersaing Produk bertanda positif terhadap Kinerja Pemasaran pada UKM batik Ciwaringin di Kabupaten Cirebon dengan koefisien regresi sebesar 0.590 artinya apabila terjadi peningkatan Keunggulan Bersaing Produk setiap satu satuan maka Kinerja Pemasaran akan meningkat sebesar 0.590, bila dilihat dari tingkat signifikansi sebesar 0,04 Hal ini menunjukkan bahwa 
keunggulan bersaing produk mempengaruhi kinerja pemasaran.

Berdasarkan hasil analisis stepwise regression dapat diketahui bahwa keunggulan bersaing produk berpengaruh terhadap kinerja pemasaran, sedangkan green product innovation dan green process innovation tidak berpengaruh terhadap kinerja pemasaran pada UKM batik Ciwaringin.

\section{PEMBAHASAN}

\subsection{Pengaruh Green Product} Innovation terhadap Keunggulan Bersaing Produk dan Kinerja Pemasaran

Menurut Kammerer (2009), green product innovation bermanfaat bagi pelanggan karena selain memiliki manfaat ramah lingkungan, green produk juga akan menghasilkan manfaat lingkungan pribadi bagi pelanggan, seperti penghematan energi.

Green Product Innovation membantu perusahaan untuk mendapatkan keunggulan kompetitif dengan membedakan produk mereka dari pesaing yang tidak melakukan green product innovation (Reinhardt , 1998) . Beberapa peneliti menyarankan bahwa green innovation pada produk perusahaan memberikan manfaat individu untuk konsumen (Ottman , 1998; Reinhardt, 1998; Belz \& Bilharz , 2005). Beberapa manfaat termasuk penghematan biaya dan energi karena peralatan lebih efisien, peningkatan kualitas dan daya tahan, medan elektromagnetik dan produk kurang beracun untuk mengurangi bahaya kesehatan. Manfaat ini tidak hanya akan menciptakan nilai yang lebih baik bagi konsumen, tetapi juga mengangkat citra perusahaan dalam mempromosikan pertumbuhan berkelanjutan.

Berdasarkan hasil analisis ternyata UKM Batik Ciwaringin Kabupaten Cirebon dalam menciptakan keunggulan bersaing produk tidak dipengaruhi green product innovation. Green Product Innovation tidak berpengaruh terhadap keunggulan bersaing produk dan kinerja pemasaran pada UKM Batik Ciwaringin di Kabupaten Cirebon. Hal ini tidak sesuai dengan hasil penelitian Chen et. al (2006), penelitian Wahid et al (2011) dan penelitian Chiou (2011) bahwa Green Product Innovation dan Green Process Innovation berpengaruh positif terhadap keunggulan kompetitif perusahaan.

\subsection{Pengaruh Green Process Innovation terhadap Keunggulan Bersaing Produk dan Kinerja Pemasaran \\ Green Process Innovation}

berpengaruh terhadap leunggulan bersaing produk pada UKM Batik Ciwaringin Kabupaten Cirebon. Green process innovation juga dikenal sebagai proses inovasi yang merupakan komposisi ramah lingkungan dari satu atau lebih proses inovasi ( misalnya , daur ulang air atau bahan bakar gas desulfurisasi ). Penelitian yang dilakukan Chen et al . ( 2006) menemukan bahwa green process innovation memiliki dampak positif pada keunggulan kompetitif perusahaan. Alasan utama untuk ini adalah bahwa dengan green process innovation, limbah dapat dikurangi dan didaur ulang serta energi digunakan dalam cara yang lebih efisien. Menurut Kuo ( 2007 ) bahwa dengan menerapkan green manufacture, bisnis akan mencapai daya saing yang lebih baik dari peningkatan kualitas dan efisien penggunaan energi dan sumber daya selama produksi. Perusahaan juga dapat mencapai keuntungan yang lebih tinggi dengan angka yang lebih rendah dari dampak lingkungan karena produk jadi mengandung lebih banyak bahan-bahan alami dan diproses tanpa bahan beracun. Green Process innovation ternyata 
tidak berpengaruh terhadap kinerja pemasaran UKM Batik Ciwaringin.

Batik Trusmi Cirebon terkenal dengan motif mega mendung, maka di Ciwaringin motif bunga dan pohon menjadi ciri khas. Selain motif, cara pembuatan batik di Ciwaringin juga berbeda. Batik dibuat dengan canting besar dan proses membatik langsung dilakukan di atas kain Batik Cirebon tanpa melalui sketsa terlebih dulu. Selain itu, satu hal yang menonjol adalah penggunaan pewarna batik. Perajin di Ciwaringin lebih memilih menggunakan pewarna alami dibandingkan pewarna kimiawi. Akibatnya warna kain batik menjadi lebih lembut bahkan seperti bladus. Namun pewarna alami dianggap ramah terhadap lingkungan. Pewarna itu berasal dari beragam tumbuh-tumbuhan, seperti daun mangga, kulit jengkol, kulit mahoni, daun tong, tembakau, dan kulit manggis. Bahan-bahan alami itu dibuat ekstraksi dan difermentasi untuk menghasilkan warnawarna alami kain batik.

Ada dua cara membuat pewarna alami batik, pertama diekstraksi dan kedua difermentasi. Diekstraksi artinya bahanbahan direbus dalam air mendidih sehingga airnya berubah warna, dan air itu yang digunakan untuk mewarnai batik. Sementara fermentasi adalah proses pembuatan warna dari dedaunan dengan cara merendam dedaunan tersebut sampai layu selama 24 jam. Air rendamannya akan berubah warna. Penggunaan pewarna alami untuk kain batik, sama seperti pewarna kimiawi. Namun karena alami, pewarna tersebut ramah lingkungan. Penggunaan pewarna alami datang dari kesadaran akan pentingnya menjaga lingkungan. Lebih-lebih belakangan ini seluruh dunia mengkampanyekan go green.

Hasil penelitian ini sesuai dengan hasil penelitian Chen et. al (2006) , penelitian Wahid et al (2011) dan penelitian
Chiou (2011) bahwa Green Product Innovation dan Green Process Innovation berpengaruh positif terhadap keunggulan kompetitif perusahaan. Jadi Green Innovation Process berpengaruh terhadap keunggulan bersaing produk batik Ciwaringin. Efek inovasi terhadap keunggulan posisi dan kinerja perusahaan tergantung pada intensitas kompetitif (He, W., \& Nie, M. 2008).

\subsection{Pengaruh Keunggulan Bersaing Produk terhadap Kinerja Pemasaran}

Keunggulan bersaing produk yang dimiliki batik Ciwaringin yang ramah lingkungan ternyata dapat meningkatkan kinerja pemasaran. Batik Ciwaringin yang dikenal memiliki keunggulan dalam proses produksi yang menggunakan bahan-bahan pewarna berasal dari alam memiliki nilai lebih di mata pelanggan. Hal tersebut dapat meningkatkan kinerja pemasaran.

Peningkatan pendapatan lebih banyak diperoleh saat keramaian meningkat seperti menjelang Idul Fitri, saat liburan sekolah, ketika mengikuti pameran-pameran bahkan saat menjelang pemilu. Produk batik Ciwaringin telah mampu dipasarkan pada beberapa daerah di luar Kabupaten Cirebon seperti Sumatra, kalimantan, Jakarta, Bali, wilayah Jawa Barat, bahkan sudah ada yang mampu memasarkan ke luar negeri seperti Australia, Malaysia, Jepang, Hongkong, Korea, negara-negara Eropa.

Kinerja perusahaan yang superior memiliki hubungan positif yang sangat tinggi dengan keunggulan bersaing perusahaan (Barney, 1991; Porter, 1985). Menurut Majeed (2011) keunggulan bersaing memiliki hubungan positif dengan kinerja perusahaan. Wang dan Lo (2003) menjelaskan hubungan antara keunggulan yang unik dengan kinerja penjualan organisasi dengan mengukur pertumbuhan 
penjualan dari tingkat pendapatan penjualan, profitabilitas, Return on investasi, hasil, nilai tambah produk dan pangsa pasar.

\section{KESIMPULAN DAN SARAN}

Berdasarkan hasil analisis dan pembahasan dapat disimpulkan green product innovation tidak berpengaruh pada keunggulan bersaing produk batik Ciwaringin tetapi green process innovation memiliki pengaruh terhadap keunggulan bersaing produk pada UKM Batik Ciwaringin di Kabupaten Cirebon. Untuk meningkatkan keunggulan bersaing sebaiknya UKM senantiasa membuat batik dengan menggunakan bahan-bahan alami yang berwawasan lingkungan. UKM senantiasa memperhatikan apa yang dibutuhkan oleh pelanggan, memenuhi selera pelanggan yang dapat berubah setiap saat seperti perubahan selera akan motif, bahan, jenis produk. Inovasi yang dilakukan oleh para pengusaha dan pengrajin selalu lahir dari kreatifitas yang tinggi.

Green Process Innovation yang semakin meningkat dapat meningkatkan keunggulan bersaing produk batik. Produk batik yang unggul dengan desain yang unik, tidak mudah ditiru, memiliki nilai lebih dari pesaingnya yaitu menggunakan bahan baku yang berasal dari alam serta memiliki dampak minimal terhadap lingkungan. Proses pembuatan batik yang menggunakan pewarna alami sehingga tidak merugikan lingkungan akan menjadi produk yang unggul. Produk batik yang unggul diharapkan dapat bersaing dengan lebih baik. Produk batik yang unggul akan mampu meningkatkan kinerja pemasaran UKM Batik Ciwaringin.

Berdasarkan analisis data dan pembahasan penulis merekomendasikan bahwa para pemilik UKM sebaiknya tetap mempertahankan proses pembuatan batik yang berwawasan lingkungan. UKM sebaiknya tetap lebih kreatif dalam melakukan inovasi terhadap produk yang membuat produk mereka unggul di pasar dengan menggunakan bahan-bahan alami yang tidak merusak lingkungan. Pemilik UKM batik Ciwaringin di Kabupaten Cirebon bisa lebih kreatif dan inovatif dalam membuat motif dan desain batik. Batik semakin bisa diterima di masyarakat dunia.

Untuk penelitian-penelitian di masa yang akan datang sebaiknya dapat melakukan penelitian dengan tema yang lebih menarik. Selain itu bisa melakukan penelitian pada objek yang berbeda selain UKM batik, jumlah sampel yang lebih banyak dan memadai. Penelitian lainnya bisa menggunakan alat analisis yang berbeda Penelitian ini memiliki beberapa keterbatasan antara lain :

a.Jumlah responden yang terbatas dengan mayoritas pemilik UKM berpendidikan SD sehingga pemahaman mengenai kuesioner masih kurang.

b.Hasil analisis menghasilkan hanya 2 hipotesis yang signifikan dari 5 hipotesis yang diajukan. 


\section{DAFTAR PUSTAKA}

Ali Ekber Akgün, İpek Koçoğlu, et al. 2012. The Relationship Between Intellectual Capital, Innovation and Competitive Advantage. Gebze Institute of Technology, Kocaeli, Turkey

Barney, J. B, 1991, "Firm Resources and Suistained Competitive Advantage", Journal of Management, 17 (1), $99-120$

Belz, F. dan Bilharz, M. 2005. Nachhaltigkeits-Marketing in Theorie und Praxis. DUV, Wiesbaden, Germany

Bodlaj, M. 2010. "The Impact Of A Responsive And Proactive Market Orientation On Innovation And Business Performance". Economic And Business Review, VOL. 12 No. 4: 241-261.

Calantone dan Di Benedetto, A. C, 1988, "An Integrative Model of New Product Development Process : An Empirical Validation", Journal of product Innovation Management, 5, 201-215

Carayannis, E.G. dan Gonzalez, E. 2003, "Creativity and innovation 1/4 competitiveness? When, how, and why?", in Shavinina, L.V. (Ed.), The International Handbook on Innovation, Elseiver, USA, pp. 587-606.

Charter, M. dan Clark, T. 2007, Sustainable Innovation: Key Conclusions from Sustainable Innovation Conferences 2003-2006: Organized by The Centre for Sustainable Development, University College for the Creative Arts, May.

Chen, Y.-S., et al. 2006. "The Influence of Green Innovation Performance on Corporate Advantage in Taiwan." Journal of Business Ethics 67: 331-339.

Chen, Y. S. 2008a. "The driver of green innovation and green image-Green core competence". Journal of Business Ethics, 81(3), 531-543.

Chen, Y. S. 2008b. "The positive effect of green intellectual capital on competitive advantages of firms". Journal of Business Ethics, 77(3), 271-286.

Chen, Y. S. 2010. "The drivers of green brand equity: Green brand image, green satisfaction, and green trust". Journal of Business Ethics, 93(2), 307-319.

Chen, Y. S., Lai, S. B., dan Wen, C. T. 2006. "The influence of green innovation performance on corporate advantage in Taiwan". Journal of Business Ethics, 81(3), 531-543.

Chiou, T. Y., Chan, H. K, Lettice, F., dan Chung, S. H. 2011.” Influence of greening the suppliers and green innovation on environmental performance and competitive advantage". Transportation Research Part E, 47, 822-836.

Cooper, 1. G, 2000, "Strategic Marketing Planning foe Radically New Products", Journal of Marketing, 64, $1-16$

Cooper, Robert G dan Elko J Kleinscmidt, 1990, New Product Success Factors : A Comparison of Kills Versus Successes and Failures, R \& D Management

Corsino, M. 2008. "Product Innovation and Firm Growth: Evidence from the Integrated Circuits Industry." DRUID Working Paper.

Coyne, K.P , 1986, Suistainable Competitive Advantage-What it is, What it isn't, Business Horizon, 29(1), 54-61

Dangelico, Rosa Maria dan Devashish Pujari, 2010, "Mainstreaming Green Product Innovation: Why and How Companies Integrate Environmental Sustainability", Journal of Business Ethics (2010) 95:471-486

Day, G. S, dan Nedungadi, P. 1994. "Managerial Representations of Competitive Advantage." Journal of Marketing Vol. 58: (April). pp.31-44

Diwekar, U. M. dan Shastri, Y. N. 2010. Green process design, green energy, and sustainability: A systems analysis perspective.

Ferdinand, Augusty, 2013, Metode Penelitian Manajemen, Badan Penerbit Universitas Diponegoro

Fred Langerak, et al. 2004. "The Impact of Market Orientation, Product Advantage, and Launch Proficiency on New Product Performance and Organizational Performance".Product Innovation_Management 21:79-94: 79-94. 
Ghozali, Imam, 2011, Model Persaman Struktural: Konsep dan Aplikasi dengan Program AMOS Ver.19.0, Badan Penerbit Universitas Diponegoro, Semarang

Grant, Robert M, 1991, "The Resource-Based Theory of Competitive Advantage : Impication for Strategy Formulation", California Management Review.

Han, J. K., N Kim, dan R. K. Srivastava. 1998. "Market Orientation and Organizational Performance : Is Innovation a Missing link?" Journal of Marketing Vol 62

He, W., dan Nie, M. 2008. "The Impact of Innovation and Competitive Intensity on Positional Advantage and Firm Performance". The Journal of American Academy of Business, Cambridge, Vol. 14 Num. 1: 205-209.

Heizer, Jay dan Barry Render, 2008, Operations Management, 9th Edition, Pearson Education, Inc, New Jersey

Hitt, M.A., R.D. Ireland, S.M, Camp D. L. Sexton, 2001, "Strategic Entrepreneurship : Entrepreneurial Strategies for Wealth Creation", Strategic Management Journal. 22. Pp 479-491

Hoonsopon, D, 2009, "The Empirical Study of The Impact of product Innovation Factors on the Performance of New Products : Radical and Incremental Product Innovation", The Business Review, Cambridge Vol.12, Num. 2, Summer.

Hsun Chang, Ching, 2011, "The Influence of Corporate Environmental ethics on Competitive Advantage : The Mediation Role of Green Innovation", Jurnal of Business Etchic, 104 : 361-370

Hua, S. Y, dan U. Wemmerlo. 2006. "Product Change, Intensity, product Advantage, and Market Performance : An Empirical Investigation on The PC Industry." Journal of Product Innovation Management. Vol 23. Issue 4. p 316-329

Jiménez-Zarco, A. I., et al. 2006. "Performance Measurement System (Pms) Integration Into New Product Innovation: A Literature Review And Conceptual Framework." Academy of Marketing Science Review.

Hunt, S. D. dan Morgan, R. M, 1995, "The Comparative Advantage Theory of Competition", Journal of Marketing, 59, 1-15

Kammerer, D., 2009, The effects of customer benefit and regulation on environmental product innovation. Empirical evidence from appliance manufacturers in Germany. : Ecological Economic.s

Kemp, R. 2006, Proposal for the MEI (Measuring ecoinnovation) project. : Maastricht

Kotler, Philip, dan Gary Amstrong, 2008., Principles of Marketing, 12th Edition, Pearson Prentice Hall, Inc, Upper Saddle River, New Jersey

Kuo, S. C. 2007, Green Manufacturing Process - Surface Pre-treatment with Micro Bubble Cavitation. IEE.

Langerak, F., Hultink, E. J., et. al 2004. "The Impact of Market Orientation, Product Advantage, and Launch Proficiency on New Product Performance and Organizational Performance." Journal of Product Innovation Management 21,: 79-94

Majeed, Sadia, 2011, "The Impact of Competitive Advantage on Organizational Performance", European Journal of Business and Management, Vol 3, No.4.

Montoya-Weiss, M. dan Calantone, R., 1994, "Determinants of new product performance." Journal of Product Innovation Management, Vol. 11, November, : pp. 397-417.

Murtadlo, Arif, 2013, Upaya Pengembangan Usaha Pengrajin Batik Malangan, Ilmu Ekonomi, Fakultas Ekonomi dan Bisnis, Universitas Brawijaya, aar0389@yahoo.com

Narver, John C dan Stanley F, Slater, 1990 : "The Effect of Market Orientation on Business Profitability", Journal of Marketing. vol. 54, pp. 20-35.

Neely, A.2005, "The Evolution of Performance Measurement Research: Developments in the Last Decade and a Research Agenda for the NEXT"'. International Journal of Operations \& Production Management, Vol. 25, No. 12, : pp. 1264-1277

Nunes, T. dan Bennett, M. J. 2010. "Green Operations Initiatives in the Automotive Industry: An Environmental Reports Analysis and Benchmarking Study". Benchmarking International Journal, Vol 17, No 3 
Ottman, J. A. 1998. Green marketing: challenges and opportunities. : NTC Business Books.

Porter, Michael E, 1985, Competitive Advantage, The Free Press, New York

Reinhardt, F. L. 1998. "Environmental product differentiation: implications for corporate strategy". California Management Review 40.

Shan Chen, Yu, Shyh-Bao Lai, dan Chao-Tung Wen, 2006, "The Influence of Green Innovation Performance on Corporate Advantage in Taiwan", Jurnal of Business Ethics. 67:331-339

Siquera, Ana Cristina o, Andy D. Cosh, 2008, "Effect of Product Innovation and Organizational Capabilities on Competitive Advantage : Evidence from UK Small and Medium Manufacturing Enterprises", International Journal of Innovation Management, Vol. 12. No. 2. Pp 113-137, Imperial College Press.

Song, M., dan Montoya-Weiss, M. M. 2001. "The Effect of Perceived Technological Uncertainty on Japanese New Product Development." The Academy of Management Journal, 44(1), :pp.61-80.

Suhong Li, Bhanu Ragu-Nathanb, T.S. Ragu-Nathanb, dan Raob, a. S. S. 2006. "The impact of supplychain management practices on competitive advantage and organizational performance". The International Journal and Management Science: 107-124.

Triebswetter danWackerbauer, 2007. Integrated environmental product innovation in the region of Munich and its impact on company competitiveness.

Wahid, Nabsiah Abdul dan Teh Ting Lee, 2011," Product, process and combined green innovations on firm's competitive advantages", Elixir Marketing Mgmt. 38 (2011) 4330-4334

Wahyono, B, 2011. "Permasalahan di UKM Batik dan Solusinya (Studi Kasus di UKM Batik Nderbolo Sragen)"

Wang, Y., dan Lo., H.P, 2003, "Customer-focused performance and the dynamic model for competence building and leveraging A resource-based view", Journal of Management Development, volume 22, pp. $483-526$

Wong, Stanley Kam-Sing, 2012 "The influence of green product competitiveness on the success of green product innovation: Empirical evidence from the Chinese electrical and electronics industry", European Journal of Innovation Management, Vol. 15 Iss: 4, pp.468 - 490

Zhou, k. Z, Yim, C. K, dan David, K. T, 2005, "The Effect of Strategic Orientation on Technology and Market-Based Breaktrough Innovation”, Journal of Marketing, 69, 42-60. 